\title{
情绪调节策略的使用与转换: 认知灵活性的促进作用
}

高伟 ${ }^{1}$, 陈圣栋 ${ }^{1}$, 陈永强 ${ }^{1}$, 何飞澜 ${ }^{1}$, 杨洁敏 ${ }^{2}$, 袁加锦 $^{2^{*}}$

1. 西南大学心理学部, 重庆 400715;

2. 四川师范大学脑与心理科学研究院, 成都 610066

*联系人, E-mail: yuanjiajin168@sicnu.edu.cn

2020-08-18 收稿, 2020-10-13 修回, 2020-10-14 接受, 2020-10-15 网络版发表

国家自然科学基金(31671164，31971018)和重庆市研究生创新研究课题(CYS18131)资助

摘要认知灵活性缺陷与情绪失调被普遍认为是抑郁、焦虑等心理疾病的典型特征. 尽管认知灵活性被认为在情 绪调节过程中发挥着重要作用，但认知灵活性对情绪调节不同方面的贡献如何及其影响机制迄今尚不清楚. 因此， 本文将结合现有理论与实证研究系统阐述认知灵活性对情绪调节的促进作用, 并从情绪调节倾向性、有效性、灵 活性及适应性4个方面重点分析其影响机制。具体而言: (1) 认知灵活性能促进个体倾向使用对身心健康发挥保护 性作用的情绪调节策略; (2) 认知灵活性能通过直接或间接的方式降低情绪反应强度来促进个体的情绪调节有效 性; (3) 认知灵活性通过促进个体对变化的情境做出快速反应为情绪调节灵活性提供必要条件; (4) 认知灵活性还 能通过降低多目标权衡中的认知负荷来提升个体的情绪调节适应性。总之, 认知灵活性通过促进个体对保护性策 略的使用, 有效降低情绪反应以及对变化的情境和目标做出快速权衡来对情绪调节发挥作用。明确认知灵活性对 情绪调节不同方面的促进作用可以帮助我们进一步理解情绪失调疾病存在认知缺陷的内在机制, 并从认知灵活性 的角度为改进抑郁、焦虑等疾病的治疗方法提供新的解决之道.

关键词认知灵活性, 情绪调节倾向, 情绪反应, 情绪调节灵活性, 适应性

灵活地适应不断变化的环境是维持人们心理健康 的一个重要因素 ${ }^{[1-4]}$. 个体内在的灵活性能够促进其生 理功能的健康发展, 而灵活性的消退和缺失可能会导 致个体出现老化和压力相关的心理疾病 ${ }^{[5,6]}$. 个体灵活 性的削弱还是慢性社会心理压力导致情绪失调疾病 (如: 焦虑症、抑有症)发生的机制之一 ${ }^{[7,8]}$. 因此，对灵 活性的深人分析和理解对个体成功地适应社会生活和 治疗心理健康疾病具有重要意义.

灵活性涵盖许多不同的类型 ${ }^{[9 \sim 11]}$, 认知灵活性作为 执行功能(executive function)的重要组成部分已受到研 究者的广泛关注. 认知灵活性这一概念最早被定义为 根据情况变化的需求产生或变换反应方式的能力 ${ }^{[12]}$,
关于执行功能的研究已经对认知灵活性在心理方面的 作用和发展进行了系统阐述 ${ }^{[13,14]}$. 根据不同领域的侧 重点, 研究者们会关注认知灵活性的不同方面. 在情绪 调节领域，认知灵活性被认为是一种根据情景需求和 个人目标, 适应性地改变思维过程的能力 ${ }^{[15 ~ 17]}$. 许多研 究发现, 认知灵活性与一系列积极的认知能力相关, 如: 集中注意力、抑制无关刺激、更好地控制思维，而不 会陷人非适应的、僵化的思维习惯当中 ${ }^{[18]}$. 这些认知 能力均与情绪调节过程存在着密切的关联. 更重要的 是，情绪调节的失败也常常与个体的认知功能失调联 系起来, 如: 焦虑症、抑有症等情绪失调疾病的产生已 被证明与个体在认知灵活性方面的缺陷有关 ${ }^{[19 \sim 21]}$. 
研究普遍认为, 认知灵活性与情绪调节之间存在 着相互影响. 例如, 发展心理学的证据就表明, 在儿童 的成长过程中, 认知灵活性和情绪调节存在双向的整 合作用, 两者可能共享相同的神经机制, 并共同促进人 格健全发展 ${ }^{[22]}$. 因此, 前人对认知灵活性与情绪调节的 研究主要从目标和功能两个方向来对两者的关系进行 考察 ${ }^{[23]}$. 一方面, 研究者们将情绪调节看作是一种心理 功能, 主要关注情绪调节对认知灵活性的影响. 例如, 个体对愤怒情绪的有效管理和认知灵活性之间存在着 正相关关系 ${ }^{[24,25]}$, 而有效的问题解决也可以显著预测 个体的高认知灵活性水平 ${ }^{[26,27]}$. 另一方面, 研究者们也 将情绪调节看作是一种目标，主要考察认知灵活性对 情绪调节的影响. 例如, 研究发现, 高水平的认知灵活 性与认知重评策略的成功使用存在正相关关系，并且 认知重评的调节效果也会受到认知灵活性的影响 ${ }^{[28,29]}$; 相反, 认知不灵活则会使个体维持元思状态, 表现为拒 绝让新信息来改变自身固有的认知或行为，导致个体 在过滤和摆脱消极信息方面有很大的困难，进而引发 一系列情绪问题 ${ }^{[27,30]}$. 近年来, 研究者们又进一步考虑 到不同情境的变化和需求, 认为认知灵活性是个体应 对和适应环境的必要条件. 有研究表明, 认知灵活性越 低的个体对连续变化情绪场景的反应越强烈，越难以 脱离负性情绪 ${ }^{[31]}$. 由此可见, 认知灵活性不仅会对情绪 调节策略的使用产生影响, 而且会在情绪调节策略变 化时发挥作用. 更为重要的是, 认知灵活性对情绪调节 的促进作用可能会进一步带来更多心理健康方面的收 益. 有研究发现, 认知灵活性可以通过促进个体进行有 效的情绪调节来提升其心理弹性与生活幸福感 ${ }^{[32]}$, 来 自正念和冥想训练的证据也表明，提升认知灵活性可 以帮助情绪失调疾病患者缓解自身的焦虑与抑郁情 绪 ${ }^{[33,34]}$. 这些结果表明, 认知灵活性对情绪调节的促进 作用能够影响个体的心理健康，进一步澄清两者的关 系能够帮助我们理解情绪调节失调的内在机制, 并为 正念冥想等治疗方法的改进提供重要参考.

如果我们要进一步分析认知灵活性对情绪调节的 促进作用, 那么首先需要确定情绪调节的哪些方面可 能会受到认知灵活性的影响. 从情绪调节被概念化之 后，有研究根据理论提出了不同的情绪调节策略来考 察个体的情绪调节能力 ${ }^{[35,36]}$. 随着研究的不断推进, 人 们逐渐从关注策略的使用倾向和调节效果(即情绪调 节的倾向性与有效性)转变到关注个体是如何灵活地 使用策略及适应不断变化的情境需求(即情绪调节的
灵活性与适应性). 例如, 早期研究通过考察不同策略与 精神病理症状之间的联系确定了哪些策略是与情绪障 碍相关的风险或保护性因素，如认知重评就被普遍认 为是一种的良好的情绪调节策略 ${ }^{[37,38]}$; 而后来研究又 发现, 情绪调节还需要考虑策略转变与情境需求, 如认 知重评与注意分散相比, 在高唤醒情境下并不适 用 ${ }^{[39,40]}$. 由此可见, 以往研究已经从策略的倾向性、有 效性、灵活性与适应性等角度对情绪调节进行了探索, 然而认知灵活性对情绪调节这4个方面的作用如何目 前尚未明晰. 因此, 本文将首先基于现有的认知控制模 型阐明认知灵活性促进情绪调节的理论基础. 然后, 结 合以往实证研究的证据从情绪调节倾向性、有效性、 灵活性及适应性 4 个方面阐述认知灵活性对情绪调节 发挥的促进作用, 并进一步分析这些作用产生的内在 机制. 最后, 提出将认知灵活性与传统心理疾病的治疗 方法相结合的设想，为深人理解认知灵活性与情绪调 节两者的关系奠定基础.

\section{1 认知灵活性促进情绪调节的理论基础}

情绪调节这一概念最早被认为是“个体受到自身 情绪的影响并了解如何对感受到的情绪进行体验和表 达的过程”[36]，其核心思想是“因为情绪是一个随时间 变化而不断产生的多成分过程，所以情绪调节应当涉 及情绪动力学的改变”. 基于此, Gross ${ }^{[36]}$ 提出情绪调节 的过程模型，该模型对情绪诱发和情绪调节发生的过 程以及两者之间的联系进行了详尽的分析, 并根据情 绪产生过程中受影响的不同阶段来区分情绪调节策略, 包括先行关注策略(antecedent-focused strategies)和反 应关注策略(response-focused strategies). 在此基础上, 结合动物和人类脑成像研究证据, Ochsner和Gross ${ }^{[41]}$ 又提出了情绪认知控制模型. 该理论模型认为, 情绪的 产生与调节是由掌管执行功能过程的前额叶-扣带回 系统和掌管各种类型的情绪性评价过程的皮层下系统 之间的交互作用而产生的，包括自下而上的情绪评价 系统和自上而下的认知控制系统. 大脑神经网络一方 面采用自下而上的方式编码刺激的情绪属性，对不同 类型的情绪进行评价, 产生不同类型的情绪反应 ${ }^{[42]}$; 另 一方面以自上而下的方式执行对情绪刺激的评价和情 绪表达或体验的认知控制，对其调节、疏导以及改变 评价情绪刺激物的方式 ${ }^{[43,44]}$. 情绪认知控制理论认为, 个体调节情绪会涉及两种高级形式的认知加工：(1) 采 用自上而下的加工过程来改变心理对情绪刺激的描述 
方式，从而使评价系统对新的描述产生反应；(2) 直接 改变行动或刺激事件所带来的情绪反应, 并在之后利 用自上而下的加工过程对这些预测性的关系进行更新. 在这两种情况下，执行功能都改变了个体对刺激和情 绪反应之间的关系表征方式 ${ }^{[45]}$. 情绪认知控制理论整 合了自上而下和自下而上两种系统的功能，强调两类 系统的相互影响可以作用于个体的情绪调节，从而帮 助人们随时根据情境的变化进行动态的反馈调整. 总 之, 在情绪调节这一动态过程中, 个体会受到内在执行 功能过程与外在环境的共同影响. 这一方面强调了执 行功能在情绪调节中的重要作用; 另一方面也提示后 续研究者需要关注调节策略与情境的相互作用.

因此, 后续研究将情境因素逐渐也纳入到研究中 来, 强调个体使用策略随情境变化的能力, 并提出情绪 调节灵活性的概念. 基于早期心理防卫机制与应对策 略的研究证据，Aldao等人 ${ }^{[4]}$ 提出了情绪调节灵活性理 论. 该理论强调, 情绪调节灵活性的关键是调节策略随 情境变化而改变, 两者在时间上的协变程度是衡量个 体情绪调节灵活性的标准. 而至于最终个体的情绪调 节行为是否具有适应性, 还要考虑它是否促进了个体 的目标寻求(goal pursuit)(外在目标, 如减肥成功; 或内 在目标, 如心情舒畅 $)^{[46-48]}$. 最近, Pruessner等人 ${ }^{[3]}$ 又基 于情绪调节灵活性理论提出了情绪调节灵活性的认知 控制框架模型. 该框架模型认为, 执行功能描述了一系 列高阶认知过程和能力 (工作记忆、认知灵活性及认 知抑制 $)^{[3,49]}$, 它允许个体能在不同的情境下进行灵活 的反应, 并成功地进行目标导向行为. 以往理论与研究 认为, 在概念上执行功能和情绪调节存在显著重叠 ${ }^{[2,50]}$, 因为两者都可以被解释为在变化的环境中以目标为导 向的监管活动的形式. 这与来自神经成像的证据保持 一致，执行功能与情绪调节都涉及额顶叶网络这两个 区域 ${ }^{[51 ~ 53]}$. 认知控制框架模型又将执行功能的 3 个成分 与动态的情绪调节灵活性(策略的抑制、更新与转移) 进行整合, 强调成功的情绪调节需要一种动态调整监 管策略以适应不断变化的情境需求和目标的能力. 基 于此, 他们还提出执行功能的 3 个成分能帮助个体根据 不断变化的情境对情绪调节过程的 3 个阶段进行监测 和调整: (1) 是否需要情绪调节策略的决定(识别阶段); (2) 从可用策略中选择调节策略(选择阶段); (3) 采用不 同策略并进行实施(实施阶段)。该理论框架提示，执行 功能在策略使用、策略变化及适应不断变化的情境需 求和目标方面都发挥着重要作用.
总之，情绪认知控制模型与情绪调节灵活性认知 控制框架的理论强化了我们对执行功能过程是如何影 响情绪调节不同方面的理解. 前者强调执行功能会在 情绪调节策略使用中发挥作用，后者强调执行功能也 会在情绪调节策略变化时产生影响，最终帮助个体达 到目标以适应变化的情境需求．尽管目前没有研究系 统考察过认知灵活性对情绪调节的影响，但基于现有 的理论基础, 认知灵活性作为执行功能的重要组成成 分之一, 我们有理由相信, 认知灵活性会对情绪调节的 不同方面发挥促进作用.

\section{2 认知灵活性在策略使用中的作用}

随着情绪调节理论与模型的提出，早期研究关注 不同情绪调节策略的使用情况，主要包括情绪调节的 倾向性与有效性. 倾向性是指个体习惯使用某种情绪 调节策略的程度. 前人研究认为, 情绪调节倾向性是一 种在日常生活中形成的个人倾向性特质 ${ }^{[4,55]}$. 有效性 指个体在面对情绪刺激时自身情绪反应的变化程度, 以往研究认为, 情绪反应程度越低则个体的情绪调节 越有效 ${ }^{[6,57]}$. 截至目前, 许多研究证据表明, 情绪失调 与情绪调节倾向性和有效性这两方面均存在密切关联, 如焦虑症、抑有症患者在使用认知重评策略时存在困 难，并且在面对负性情绪刺激时的主观体验与生理反 应都明显高于健康个体 ${ }^{[58,59]}$. 来自临床研究证据则表 明，认知灵活性缺陷是焦虑、抑郁等疾病的典型特征， 因此认知灵活性可能会在情绪调节倾向性和有效性这 两个方面发挥作用.

\section{1 认知灵活性与情绪调节倾向性}

前人研究已经考察了不同情绪调节倾向性与心理 健康问题之间的联系，以确定哪些策略是与心理健康 相关的风险因素或保护性因素. 认知灵活性被认为与 积极的认知能力相关, 如能更快地转变思维而不会陷 人僵化的思维习惯当中 ${ }^{[18]}$, 并且缺乏认知灵活性已经 被证明与各种不良心理健康问题有关，包括抑郁症、 焦虑症和精神分裂症等 ${ }^{[17,20,21]}$. 因此，在个体的身体与 心理健康方面，发挥保护性作用的情绪调节倾向可能 会受益于认知灵活性的促进作用. 研究者们基于情绪 调节理论与模型相继开发出不同的量表与问卷来衡量 个体的情绪调节倾向性，如: 情绪调节问卷、反刍思维 量表等，并检验了不同情绪调节倾向与个人的健康状 况、人际关系、工作表现及生活幸福感之间的关 
系 ${ }^{[60 \sim 62]}$. 例如, Gross 和John ${ }^{[62]}$ 通过情绪调节问卷测量 个体使用认知重评与表达抑制两种情绪调节策略的倾 向, 结果发现, 认知重评与更良好的人际关系、更高的 生活幸福感呈正相关关系，而表达抑制倾向的个体会 有更差的人际关系、更低的生活幸福感. 精神病理学 研究也发现, 具有认知重评倾向的个体会有更低的抑 郁水平, 而高反刍倾向则认为是抑郁症患者的典型情 绪调节特征 ${ }^{[63 \sim 65]}$. 因此，相比于表达抑制与反刍等策 略, 习惯使用认知重评已被认为是一种对心理健康具 有保护性作用的情绪调节倾向 ${ }^{[37,50]}$ ，那么个体对认知 重评策略的倾向性使用就可能会受益于认知灵活性的 促进作用. 进一步地, 目前已有研究对认知灵活性与认 知重评的关系进行了考察. 实验研究证据发现, 认知灵 活性与成功的认知重评之间存在关联, 例如, 研究发现, 认知灵活性与重评时的右侧额下回激活水平呈负相关. 这表明, 高认知灵活性个体更容易进行认知重评 ${ }^{[29]}$. 发 展心理学的研究证据也表明, 高认知灵活性能促进概 念重构(concept reconstruction), 这也是认知重评的关 键 $^{[6,66]}$. 另外, 研究还发现, 正念认知疗法可以通过增强 认知灵活性打破习惯性反应，帮助获取更广泛的信息 并产生新的情景评估, 从而提升个体的认知重评能

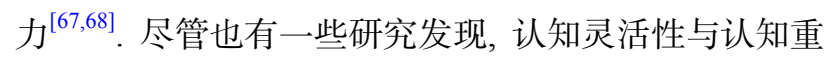
评不存在关联 ${ }^{[69,70]}$, 但研究认为, 这是由于实验所使用 的任务范式不能完全表征认知灵活性所导致的, 例如, Guassi Moreira等人 ${ }^{[69]}$ 认为, 使用逆转学习任务来测量 认知灵活性并不是有效的.

总之，考虑到认知重评作为心理健康的保护性因 素, 并且与高认知灵活性之间存在密切关联, 我们认为 个体使用认知重评策略的倾向会受益于认知灵活性的 促进作用.

\section{2 认知灵活性与情绪调节有效性}

关于情绪调节倾向性的研究已经考察了不同的调 节策略与个体心理健康状况的关系. 然而这些研究往 往缺少对真实情绪反应的检验. 病理学研究已经表明, 焦虑症、抑有症等疾病会伴随着个体情绪反应的异常, 如: 行为与脑科学的研究结果证实, 抑有症患者在面对 负性刺激时其主观情绪体验与杏仁核激活水平均显著 高于健康个体 ${ }^{[59,71,72]}$. 前人实验研究也发现, 认知灵活 性与个体的情绪反应之间存在关联, 如: 来自动物研究 的证据表明，认知灵活性与情绪反应不是相互独立的， 低水平认知灵活性与高水平情绪反应有关 ${ }^{[73]}$; 一些实
验研究也发现, 提升认知灵活性能够减少个体在挫折 情境中的愤怒情绪体验 ${ }^{[22]}$. 因此, 认知灵活性可能对情 绪调节的有效性也发挥着促进作用. 然而, 截至目前, 我们仍不清楚认知灵活性是通过促进个体对情绪调节 策略的使用进而影响情绪调节有效性，还是它能够直 接影响个体的情绪反应进而作用于情绪调节有效性. 一方面, 如前文所述, 高认知灵活性会帮助个体更易于 使用认知重评进而导致情绪反应的降低, 并且以往研 究也发现, 与认知灵活性存在关联的脑区(如背外侧前 额叶)与情绪调节过程中抑制杏仁核活动的脑区存在 重叠 ${ }^{[74,75]}$, 这就为认知灵活性通过情绪调节影响杏仁 核的反应提供了可能性. 例如, 近期一项脑影像研究结 果表明, 认知灵活性与个体在认知重评任务中的杏仁 核激活水平呈负相关关系 ${ }^{[29]}$. 另一方面, 也有一些研究 表明, 认知灵活性可能会直接影响个体的情绪反应. 例 如, 行为研究发现, 高认知灵活性能帮助个体在工作环 境发生变化时表现出更少的消极情绪反应 ${ }^{[76]}$. 关于创 造力的研究结果也发现, 高认知灵活性能够帮助个体 维持积极情感的延续进而保持高创造力水平 ${ }^{[77]}$. 另外, 来自动物与人类研究的神经生物学证据也提示, 认知 灵活性可能对情绪反应产生直接影响 ${ }^{[73,78]}$, 如: 有研究 者发现, 个体认知灵活性的增强会减弱下丘脑-垂体-肾 上腺(hypothalamo-pituitary adrenal, HPA)轴的六奋状态 从而降低个体的情绪反应，这可能与大脑中齿状回的 功能有关 ${ }^{[78]}$.

总之, 尽管已有研究还未能揭示, 认知灵活性对情 绪调节有效性的作用机制，但无论是间接还是直接的 途径, 认知灵活性与个体情绪反应之间的关联性都已 被证明存在. 这表明, 认知灵活性会对情绪调节的有效 性发挥促进作用.

\section{3 认知灵活性在策略变化中的作用}

近年来, 随着情绪调节研究的不断深人, 人们发现, 只关注情绪调节策略的使用而不考虑情境的变化和需 求是不合理的. 越来越多的研究证据也表明, 情绪调节 最终是否能够让人受益取决于个体根据情境变化与需 求灵活地选择和使用不同策略的能力 ${ }^{[79 ~ 82]}$, 即考虑情 绪调节灵活性与适应性的重要作用. 前人理论认为, 灵 活性是指, 个体根据情境变化快速地进行情绪调节的 能力; 适应性则是指, 个体根据情境需求调节情绪并最 终帮助个人实现目标的能力 ${ }^{[4,50,83]}$. 如前所述, 前人理 论与研究已将认知灵活性认为是一种当环境偶发事件 
发生变化时, 个体能够考虑多种想法, 灵活转换认知模 式, 改变习惯性反应模式的一种高级认知能力. 因此, 考虑到情绪调节灵活性与适应性会涉及情境与目标需 求的变化, 我们认为, 认知灵活性也可能会在情绪调节 灵活性与适应性这两个方面发挥促进作用。需要注意 的是，情绪调节灵活性与适应性的成立是以倾向性与 有效性的存在为前提：只有当个体存在情绪调节的意 愿并能有效使用调节策略时，讨论个体的灵活性与适 应性才是有意义的. 而适应性作为个体适应环境的最 终目的, 其与前三者的关系也需要在未来研究中被进 一步探讨.

\section{1 认知灵活性与情绪调节灵活性}

在现实生活中人们往往会面临复杂且多变的情境, 个体可能会根据情境的改变来变换自身所使用的情绪 调节策略, 即情绪调节灵活性. 前人理论与研究都认为, 认知灵活性能够帮助个体转换思维方式，并抑制习惯 化行为, 以应对变化的外部条件, 在适应情境变化中发 挥着重要作用 ${ }^{[9,68,84]}$. 因此，当调节策略跟随情境改变 而发生变化时, 个体的情绪调节灵活性可能会受到认 知灵活性的影响. 尽管目前为止还没有研究证据直接 确定认知灵活性与情绪调节灵活性的关系，但从理论 概念与实证研究这两个视角进行分析能够帮助我们进 一步理解两者的关系. 一方面, 从概念上来讲, 认知灵 活性被定义为个体根据需求和情境的变化产生或变换 认知与反应方式的能力, 情绪调节灵活性被界定为是 个体随着情境的变化而改变认知策略的能力，两者在 概念上存在着重叠 ${ }^{[4,9]}$. 并且两者都关注于个体在应对 情境变化时反应的快慢程度. 认知灵活性需要个体尽 快对新信息进行认知加工，情绪调节灵活性则要求个 体尽快在新场景中进行情绪调节。在不断变化的环境 中, 认知灵活性帮助个体首先通过将注意力集中在变 化中的元素来识别自身所处的环境是如何变化的. 在 确定之前的调节策略在新的环境中不合适后，认知灵 活性又能帮助个体抑制以前的反应并重新配置新的调 节策略 ${ }^{[85}$. 因此, 从概念上来看, 认知灵活性可能是情 绪调节灵活性的必要条件. 另一方面, 实证研究已经从 3 个方面对情绪调节灵活性进行了考察，包括场景变 化、策略变化及策略场景的同步变化 ${ }^{[86]}$. 关于场景变 化的研究主要考察个体跟随情境灵活地上调和下调情 绪的能力，如测量被试在情感认知集和非情感认知集 之间的转换成本来衡量个体的情绪调节灵活性, 结果
发现，拥有较高水平灵活性的个体能使用更少的转换 成本下调自身负性情绪 ${ }^{[87]}$. 而关于策略变化的研究则 主要考察不同的调节策略在不同场景中的使用效果， 如前人研究结果表明，在低唤醒度的情绪场景中被试 选择使用认知重评的调节效果更好，而在高唤醒度的 情绪场景中使用注意分散策略则会带来更多的收 益 $^{[88,89]}$. 虽然目前关于策略场景同步变化的研究还较 少, 但这些研究也都会涉及情境变化这一因素. 由此可 见, 情境变化是情绪调节灵活性 3 个方面研究中的重要 组成部分. 进一步地, 一些研究提示, 认知灵活性在情 境变化中也发挥着重要作用. 例如, 一项研究使用心率 变异性(heart rate variability, HRV)来考察个体的认知灵 活性, 结果发现, 被试的认知灵活性越低对连续变化的 情绪场景的反应越强烈, 也越难以脱离 ${ }^{[31]}$.

因此, 基于目前的理论与研究认为, 认知灵活性是 情绪调节灵活性的必要条件, 在根据情境变换调节策 略的过程中，情绪调节灵活性可能是认知灵活性的具 体表现形式. 认知灵活性对情绪调节灵活性发挥着促 进作用, 能够帮助个体对变化的情境作出快速反应.

\section{2 认知灵活性与情绪调节适应性}

研究认为, 如果个体最终要从情绪调节中受益, 那 么就要求所使用的情绪调节策略能够帮助个体完成自 身追求的目标，即考虑到情绪调节适应性的重要性. 一 方面，目标为生活提供了方向，激发个人动机，指导个 人行为, 是完成各种发展任务的基石(如: 成功的减肥、 顺利的升职、良好的交际 $)^{[48,90]}$. 另一方面, 目标的实现 也能促进个体形成有利于自身成功发展的长期模式, 而目标的失败则会给个体的生活质量和幸福感带来危 机, 并可能引发心理压力与身体健康问题 ${ }^{[46,91]}$. 因此可 以从促进目标实现的角度来理解认知灵活性对情绪调 节适应性的作用. 首先, 当个体的目标是情绪调节目标 时，前文已经阐述认知灵活性可以通过从促进个体对 调节策略的使用来帮助实现情绪调节目标. 其次, 当目 标是非情绪调节目标时，认知灵活性也可以通过促进 快速的问题解决让个体受益 ${ }^{[92,93]}$, 例如，认知灵活性能 够通过促进对记忆目标的寻求过程从而提升个体的学 习能力. 更重要的是, 人们在现实生活中会面临复杂多 变的情境, 多种目标可能会同时存在(如: 演讲时既要缓 解紧张情绪, 也要记忆演讲词). 然而, 同时处理多种目 标会带来巨大的认知负荷，有限的认知资源就要求我 们对不同的目标进行权衡 ${ }^{[94-96]}$. 许多研究已经表明, 认 
知灵活性会在目标寻求与调整中发挥促进作用, 认知 灵活性能够保护当前的行动目标不受干扰, 同时监控 正在进行的行动与结果之间的关系, 然后根据结果调 整未来的行动以促进目标的实现 ${ }^{[19,85,97]}$. 例如, 有研究 发现, 心理弹性(psychological resilience)作为一种灵活 应对压力事件与适应情境需求变化的能力能够受益于 认知灵活性的促进作用 ${ }^{[32]}$. 另外, 即使当目标无法达成 时, 认知灵活性也对个体的后续行为产生着积极影 响 ${ }^{[98,99]}$ : 一方面, 认知灵活性可以通过促进情绪调节帮 助个体快速缓解由目标失败所带来的负性情绪体验; 另一方面, 认知灵活性也能够帮助个体尽快脱离旧目 标, 形成新目标, 并重新配置一个人对新目标的反应.

综上可知, 无论是对单一目标的寻求方面, 还是对 多种目标的权衡方面, 认知灵活性都对情绪调节适应 性发挥着促进作用.

\section{4 总结与展望}

总之, 情绪调节的认知控制模型强调了执行功能 对情绪调节的影响, 为理解认知灵活性对情绪调节的 促进作用提供了理论依据. 基于现有理论与实证研究, 认知灵活性能够从情绪调节倾向性、有效性、灵活性 及适应性4个方面对情绪调节发挥促进作用: (1) 对身 心健康发挥保护性作用的情绪调节策略可能会受益于 认知灵活性, 认知灵活性能促进个体对认知重评的倾 向性使用; (2) 认知灵活性可能会通过间接(提升调节 策略效果)或直接(影响情绪反应强度)两条途径对情绪 调节有效性发挥促进作用; (3) 认知灵活性是情绪调节 灵活性的必要条件，在根据情境变换调节策略的过程 中，情绪调节灵活性可能是认知灵活性的具体表现形 式，能够促进个体对变化的情境做出快速反应；(4) 认 知灵活性可能通过灵活地在多种个人目标之间进行权 衡来降低认知负荷, 帮助实现目标寻求行为进而促进 情绪调节的适应性. 另外, 值得注意的是, 情绪调节倾 向性、有效性、灵活性与适应性四者并不是平行的关 系 ${ }^{[2,450]}$. 因为适应性需要个体兼具良好的调节方式, 有 效的情绪反应及灵活的策略变化, 前三者是提升个体 情绪调节适应性的重要前提条件. 因此, 我们也推测, 认知灵活性与情绪调节适应性的关系最为密切, 也就 是说, 相比于前三者, 认知灵活性可能对情绪调节适应 性发挥更强的促进作用.

总之, 一方面, 在个体使用情绪调节策略时, 认知
灵活性通过使个体倾向使用保护性调节策略及有效缓 解情绪反应来发挥促进作用; 另一方面, 在个体变换情 绪调节策略时，认知灵活性又通过帮助个体对情境变 化做出快速反应及降低在多目标权衡中的认知负荷来 发挥促进作用. 从以上 4 个方面来理解认知灵活性对情 绪调节的促进作用可以帮助我们进一步明晰存在认知 缺陷的情绪失调疾病的内在机制, 并为焦虑、抑郁等 心理疾病相关的认知疗法与认知灵活性的结合及改进 提供重要参考. 未来研究也可以从这 4 个不同方面对认 知灵活性与情绪调节的关系进行探究: (1) 有研究发现, 执行功能的其他成分(如工作记忆)也与认知重评之间 存在关联 ${ }^{[30]}$, 进一步考察执行功能的不同成分是否对 情绪调节倾向会产生协同的促进作用是必要的; (2) 如 前文所述，现有研究证据无法确定认知灵活性是间接 还是直接作用于个体的情绪反应，未来可以通过控制 情绪调节倾向性来直接检验认知灵活性与情绪反应的 关系；(3) 前人认为，情绪调节灵活性是认知灵活性的 子集 ${ }^{[2]}$, 进一步探究情绪调节灵活性的内在机制可能对 区分和揭示认知灵活性中与情绪调节相关的特异性脑 区有帮助; (4) 尽管我们认为, 认知灵活性对情绪调节 适应性发挥促进作用, 但也有研究提示, 两者之间可能 并不是线性关系 ${ }^{[86,100]}$, 例如, 在女性群体中过高的认知 灵活性可能与过度关注或分析情感有关，反而会导致 情绪调节适应性降低 ${ }^{[101]}$. 因此, 未来研究还需要对两 者的关系作进一步的探究. 另外, 来自认知神经领域的 研究证据显示, 认知灵活性下降会导致个体对负性情 绪的易感，这与其前额叶及前扣带回皮层的激活异常 有关 ${ }^{[19,22]}$; 而通过对背外侧前额叶皮层进行经颖直流 电刺激, 研究者发现, 这可能有助于提升个体的认知灵 活性, 从而加快对负性情感刺激的脱离 ${ }^{[75,102]}$. 更为重要 的是, 背外侧与腹内侧前额叶的功能已被证明是影响 抑有症与焦虑症症状的重要因素 ${ }^{[103,104]}$. 因此, 为了进 一步理解认知灵活性与情绪失调疾病之间的内在机制, 从倾向性、有效性、灵活性及适应性 4 个方面深入探 究认知灵活性影响情绪调节的神经机制是必要的. 据 此, 一方面, 可以从行为上根据认知灵活性任务来设计 正念冥想训练, 来间接提升个体的情绪调节能力; 另一 方面, 还可以将经颖电刺激作用于认知灵活性与情绪 调节存在交互的脑区，来直接影响个体的情绪调节效 果. 这些方法的尝试可能为未来抑郁症、焦虑症等疾 病的治疗提供新的解决之道. 
1 Hauser T U, Iannaccone R, Walitza S, et al. Cognitive flexibility in adolescence: Neural and behavioral mechanisms of reward prediction error processing in adaptive decision making during development. Neuroimage, 2015, 104: 347-354

2 Bonanno G A, Burton C L. Regulatory flexibility. Perspect Psychol Sci, 2013, 8: 591-612

3 Pruessner L, Barnow S, Holt D V, et al. A cognitive control framework for understanding emotion regulation flexibility. Emotion, 2020, 20: 2129

4 Aldao A, Sheppes G, Gross J J. Emotion regulation flexibility. Cogn Ther Res, 2015, 39: 263-278

5 Blanchard-Fields F. Flexible and adaptive socio-emotional problem solving in adult development and aging. Restor Neurol Neurosci, 2009, 27: $539-550$

6 Johnco C, Wuthrich V M, Rapee R M. The role of cognitive flexibility in cognitive restructuring skill acquisition among older adults. J Anxiety Disord, 2013, 27: 576-584

7 Rozanski A, Kubzansky L D. Psychologic functioning and physical health: A paradigm of flexibility. Psychosom Med, 2005, 67: S47-S53

8 Kashdan T B, Rottenberg J. Psychological flexibility as a fundamental aspect of health. Clin Psychol Rev, 2010, 30: 865-878

9 Cañas J J, Fajardo I, Salmerón L. Cognitive Flexibility. New York: Springer, 2011

10 Maren W, Seivert N H, Bonanno G A. Expressive flexibility. Emotion, 2010, 10: 92-100

11 Cunningham W A, Van Bavel J J, Johnsen I R. Affective flexibility. Psychol Sci, 2008, 19: 152-160

12 Cipolotti L, Warrington E K. Neuropsychological assessment. J Neurol Neurosurg Psychiatry, 1995, 58: 655-664

13 Diamond A. Executive functions. Annu Rev Psychol, 2013, 64: 135-168

14 Li M H, Bai X J. The research progress of the development of cognitive flexibility in executive function (in Chinese). Psychol Explor, 2005, 25: 35-38 [李美华, 白学军. 执行功能中认知灵活性发展的研究进展. 心理学探新, 2005, 25: 35-38]

15 Hildebrandt L K, McCall C, Engen H G, et al. Cognitive flexibility, heart rate variability, and resilience predict fine-grained regulation of arousal during prolonged threat. Psychophysiology, 2016, 53: 880-890

16 Lieberman L, Gorka S M, Sarapas C, et al. Cognitive flexibility mediates the relation between intolerance of uncertainty and safety signal responding in those with panic disorder. Cogn Emot, 2015, 30: 1495-1503

17 Murphy F C, Michael A, Sahakian B J. Emotion modulates cognitive flexibility in patients with major depression. Psychol Med, 2012, 42: 13731382

18 Fröding B, Osika W. Cognitive flexibility. In: Froding B, Osika W, eds. Neuroenhancement: How Mental Training and Meditation Can Promote Epistemic Virtue. Springer Briefs in Ethics. Cham: Springer, 2015

19 Kim P, Jenkins S E, Connolly M E, et al. Neural correlates of cognitive flexibility in children at risk for bipolar disorder. J Psychiatr Res, 2012, 46: $22-30$

20 Han K, Young Kim I, Kim J J. Assessment of cognitive flexibility in real life using virtual reality: A comparison of healthy individuals and schizophrenia patients. Comput Biol Med, 2012, 42: 841-847

21 Lee J K, Orsillo S M. Investigating cognitive flexibility as a potential mechanism of mindfulness in generalized anxiety disorder. J Behav Ther Exp Psychiatry, 2014, 45: 208-216

22 Li Y, Grabell A S, Wakschlag L S, et al. The neural substrates of cognitive flexibility are related to individual differences in preschool irritability: A fNIRS investigation. Dev Cogn Neurosci, 2017, 25: 138-144

23 Koole S L. The psychology of emotion regulation: An integrative review. Cogn Emot, 2009, 23: 4-41

24 Schieman S. Education and the activation, course, and management of anger. J Health Soc Behav, 2000, 41: 20-39

25 Cayanus J L, Martin M M, Weber K D. The relationships between driver anger and aggressive communication traits. Commun Res Rep, 2005, 22: 189-197

26 Silver J A, Hughes J D, Bornstein R A, et al. Effect of anxiolytics on cognitive flexibility in problem solving. Cogn Behav Neurol, 2004, 17: 9397

27 Goetter E M. An empirical investigation of depressive rumination: Implications for cognitive flexibility, problem solving and depression. Doctor Dissertation. Philadelphia: Drexel University, 2010

28 Malooly A M. The role of affective flexibility and cognitive flexibility in effective antecedent-focused and online reappraisal. Doctor Dissertation. Miami: University of Miami, 2012

29 Zaehringer J, Falquez R, Schubert A L, et al. Neural correlates of reappraisal considering working memory capacity and cognitive flexibility. Brain Imag Behav, 2018, 12: 1529-1543

30 Davis R N, Nolen-Hoeksema S. Cognitive inflexibility among ruminators and nonruminators. Cogn Ther Res, 2000, 24: 699-711 
31 Fujimura T, Okanoya K. Heart rate variability predicts emotional flexibility in response to positive stimuli. Psychology, 2012, 3: 578-582

32 Genet J J, Siemer M. Flexible control in processing affective and non-affective material predicts individual differences in trait resilience. Cogn Emot, 2011, 25: 380-388

33 Moore A, Malinowski P. Meditation, mindfulness and cognitive flexibility. Consc Cogn, 2009, 18: 176-186

34 Masicampo E J, Baumeister R F. Relating mindfulness and self-regulatory processes. Psychol Inq, 2007, 18: 255-258

35 Kashdan T B, Barrios V, Forsyth J P, et al. Experiential avoidance as a generalized psychological vulnerability: Comparisons with coping and emotion regulation strategies. Behav Res Ther, 2006, 44: 1301-1320

36 Gross J J. Antecedent- and response-focused emotion regulation: Divergent consequences for experience, expression, and physiology. J Pers Soc Psychol, 1998, 74: 224-237

37 Haga S M, Kraft P, Corby E K. Emotion regulation: Antecedents and well-being outcomes of cognitive reappraisal and expressive suppression in cross-cultural samples. J Happiness Stud, 2007, 10: 271-291

38 Jacobson B, Gail J. What processes promote resilience? The role of positive emotion, cognitive flexibility and reappraisal. Doctor Dissertation. Miami: University of Miami, 2008

39 Silvers J A, Weber J, Wager T D, et al. Bad and worse: Neural systems underlying reappraisal of high- and low-intensity negative emotions. Soc Cogn Affect Neurosci, 2015, 10: 172-179

40 Troy A S, Shallcross A J, Mauss I B. A person-by-situation approach to emotion regulation. Psychol Sci, 2013, 24: 2505-2514

41 Ochsner K N, Gross J J. The neural architecture of emotion regulation. In: Gross J J, ed. Handbook of Emotion Regulation. New York: The Guilford Press, 2007, 1. 87-109

42 Goldin P R, McRae K, Ramel W, et al. The neural bases of emotion regulation: Reappraisal and suppression of negative emotion. Biol Psychiatry, 2008, 63: 577-586

43 Ochsner K N, Gross J J. The cognitive control of emotion. Trends Cogn Sci, 2005, 9: 242-249

44 Wager T D, Davidson M L, Hughes B L, et al. Prefrontal-subcortical pathways mediating successful emotion regulation. Neuron, 2008, 59: 10371050

45 Kanske P, Heissler J, Schönfelder S, et al. How to regulate emotion? Neural networks for reappraisal and distraction. Cereb Cortex, 2010, 21: $1379-1388$

46 Brandtstädter J. Goal pursuit and goal adjustment: Self-regulation and intentional self-development in changing developmental contexts. Adv Life Course Res, 2009, 1: 52-62

47 Rasmussen H N, Wrosch C, Scheier M F, et al. Self-regulation processes and health: The importance of optimism and goal adjustment. J Pers, 2006, 74: 1721-1748

48 Wrosch C, Scheier M F, Miller G E. Goal adjustment capacities, subjective well-being, and physical health. Soc Pers Psychol Compass, 2013, 7: $847-860$

49 Miyake A, Friedman N P, Emerson M J, et al. The unity and diversity of executive functions and their contributions to complex "frontal lobe" tasks: A latent variable analysis. Cogn Psychol, 2000, 41: 49-100

50 Gross J J. Emotion regulation: Current status and future prospects. Psychol Inquiry, 2015, 26: 1-26

51 Braunstein L M, Gross J J, Ochsner K N. Explicit and implicit emotion regulation: A multi-level framework. Soc Cogn Affect Neurosci, 2017, 12: $1545-1557$

52 Ochsner K N, Silvers J A, Buhle J T. Functional imaging studies of emotion regulation: A synthetic review and evolving model of the cognitive control of emotion. Ann NY Acad Sci, 2012, 1251: E1-E24

53 Niendam T A, Laird A R, Ray K L, et al. Meta-analytic evidence for a superordinate cognitive control network subserving diverse executive functions. Cogn Affect Behav Neurosci, 2012, 12: 241-268

54 Drabant E M, McRae K, Manuck S B, et al. Individual differences in typical reappraisal use predict amygdala and prefrontal responses. Biol Psychiatry, 2009, 65: 367-373

55 Vanderhasselt M A, Baeken C, Van Schuerbeek P, et al. Inter-individual differences in the habitual use of cognitive reappraisal and expressive suppression are associated with variations in prefrontal cognitive control for emotional information: An event related fMRI study. Biol Psychol, 2013, 92: 433-439

56 Mulej Bratec S, Xie X, Schmid G, et al. Cognitive emotion regulation enhances aversive prediction error activity while reducing emotional responses. Neuroimage, 2015, 123: 138-148

57 Cohen N, Mor N, Henik A. Linking executive control and emotional response. Clin Psychol Sci, 2015, 3: 15-25

58 Kanske P, Heissler J, Schönfelder S, et al. Neural correlates of emotion regulation deficits in remitted depression: The influence of regulation strategy, habitual regulation use, and emotional valence. Neuroimage, 2012, 61: 686-693

59 Siegle G J, Thompson W, Carter C S, et al. Increased amygdala and decreased dorsolateral prefrontal BOLD responses in unipolar depression: 
Related and independent features. Biol Psychiatry, 2007, 61: 198-209

60 Balzarotti S, Biassoni F, Villani D, et al. Individual differences in cognitive emotion regulation: Implications for subjective and psychological well-being. J Happiness Stud, 2016, 17: 125-143

61 McRae K, Jacobs S E, Ray R D, et al. Individual differences in reappraisal ability: Links to reappraisal frequency, well-being, and cognitive control. J Res Pers, 2012, 46: 2-7

62 Gross J J, John O P. Individual differences in two emotion regulation processes: Implications for affect, relationships, and well-being. J Pers Soc Psychol, 2003, 85: 348-362

63 Spasojević J, Alloy L B. Rumination as a common mechanism relating depressive risk factors to depression. Emotion, 2001, 1: 25-37

64 Whitmer A J, Banich M T. Trait rumination and inhibitory deficits in long-term memory. Cogn Emot, 2010, 24: 168-179

65 Zetsche U, D’Avanzato C, Joormann J. Depression and rumination: Relation to components of inhibition. Cogn Emot, 2012, 26: 758-767

66 Johnco C, Wuthrich V M, Rapee R M. The influence of cognitive flexibility on treatment outcome and cognitive restructuring skill acquisition during cognitive behavioural treatment for anxiety and depression in older adults: Results of a pilot study. Behav Res Ther, 2014, 57: 55-64

67 Troy A S, Shallcross A J, Davis T S, et al. History of mindfulness-based cognitive therapy is associated with increased cognitive reappraisal ability. Mindfulness, 2013, 4: 213-222

68 Garland E L, Hanley A, Farb N A, et al. State mindfulness during meditation predicts enhanced cognitive reappraisal. Mindfulness, 2015, 6: 234242

69 Guassi Moreira J F, Sahi R, Ninova E, et al. Performance and belief-based emotion regulation capacity and tendency: Mapping links with cognitive flexibility and perceived stress. Emotion, 2020, doi: 10.1037/emo0000768

70 Qiu L Y, Chen C Y, Li J, et al. The effects of emotions and emotion regulation strategies on cognitive flexibility (in Chinese). China J Health Psychol, 2015, 23: 421-425 [仇璐昱, 陈彩燕, 李静, 等. 情绪及情绪调节策略对认知灵活性的影响. 中国健康心理学杂志, 2015, 23: 421425]

71 Laeger I, Dobel C, Dannlowski U, et al. Amygdala responsiveness to emotional words is modulated by subclinical anxiety and depression. Behav Brain Res, 2012, 233: 508-516

72 Smoski M J, LaBar K S, Steffens D C. Relative effectiveness of reappraisal and distraction in regulating emotion in late-life depression. Am J Geriatr Psychiatry, 2014, 22: 898-907

73 Erhard H W, Boissy A, Rae M T, et al. Effects of prenatal undernutrition on emotional reactivity and cognitive flexibility in adult sheep. Behav Brain Res, 2004, 151: 25-35

74 Quiñones-Camacho L E, Fishburn F A, Camacho M C, et al. Cognitive flexibility-related prefrontal activation in preschoolers: A biological approach to temperamental effortful control. Dev Cogn Neurosci, 2019, 38: 100651

75 Aboulafia-Brakha T, Manuel A L, Ptak R. Prefrontal transcranial direct current stimulation facilitates affective flexibility. Neuropsychologia, 2016, 86: $13-18$

76 Chung S H, Su Y F, Su S W. The impact of cognitive flexibility on resistance to organizational change. Soc Behav Pers, 2012, 40: 735-745

77 Hirt E R, Devers E E, McCrea S M. I want to be creative: Exploring the role of hedonic contingency theory in the positive mood-cognitive flexibility link. J Pers Soc Psychol, 2008, 94: 214-230

78 Anacker C, Hen R. Adult hippocampal neurogenesis and cognitive flexibility—Linking memory and mood. Nat Rev Neurosci, 2017, 18: 335-346

79 Suri G, Sheppes G, Young G, et al. Emotion regulation choice: The role of environmental affordances. Cogn Emot, 2018, 32: 963-971

80 Aldao A. The future of emotion regulation research. Perspect Psychol Sci, 2013, 8: 155-172

81 Morawetz C, Bode S, Baudewig J, et al. Neural representation of emotion regulation goals. Hum Brain Mapp, 2016, 37: 600-620

82 Windsor T D. Persistence in goal striving and positive reappraisal as psychosocial resources for ageing well: A dyadic analysis. Aging Ment Health, 2009, 13: 874-884

83 Kobylińska D, Kusev P. Flexible emotion regulation: How situational demands and individual differences influence the effectiveness of regulatory strategies. Front Psychol, 2019, 10: 72

84 Ionescu T. Exploring the nature of cognitive flexibility. New Ideas Psychol, 2012, 30: 190-200

85 Dajani D R, Uddin L Q. Demystifying cognitive flexibility: Implications for clinical and developmental neuroscience. Trends Neurosci, 2015, 38: $571-578$

86 Zhang S H, Sang B, Pan T T, et al. Emotion regulation flexibility: An integrative review (in Chinese). J Psychol Sci, 2017, 40: 905-912 [张少华, 桑标, 潘婷婷, 等. 情绪调节灵活性的研究进展. 心理科学, 2017, 40: 905-912]

87 Malooly A M, Genet J J, Siemer M. Individual differences in reappraisal effectiveness: The role of affective flexibility. Emotion, 2013, 13: 302313

88 Shafir R, Thiruchselvam R, Suri G, et al. Neural processing of emotional-intensity predicts emotion regulation choice. Soc Cogn Affect Neurosci, 2016, 11: 1863-1871 
89 Shafir R, Schwartz N, Blechert J, et al. Emotional intensity influences pre-implementation and implementation of distraction and reappraisal. Soc Cogn Affect Neurosci, 2015, 10: 1329-1337

90 Bargh J A, Gollwitzer P M. Environmental control of goal-directed action: Automatic and strategic contingencies between situations and behavior. Nebr Symp Mot, 1994, 41: 71-124

91 Heckhausen J, Wrosch C, Schulz R. A motivational theory of life-span development. Psychol Rev, 2010, 117: 32-60

92 Hermer-Vazquez L. Language, space, and the development of cognitive flexibility in humans: The case of two spatial memory tasks. Cognition, 2001, 79: 263-299

93 Johann V, Könen T, Karbach J. The unique contribution of working memory, inhibition, cognitive flexibility, and intelligence to reading comprehension and reading speed. Child Neuropsychol, 2020, 26: 324-344

94 Neal A, Ballard T, Vancouver J B. Dynamic self-regulation and multiple-goal pursuit. Annu Rev Organ Psychol Organ Behav, 2017, 4: 401-423

95 DeShon R P, Brown K G, Greenis J L. Does self-regulation require cognitive resources? Evaluation of resource allocation models of goal setting. J Appl Psychol, 1996, 81: 595-608

96 Werther B, Schnieder E. Formal Cognitive Resource Model: Modeling of human behavior in complex work environments. In: International Conference on Computational Intelligence for Modelling, Control and Automation and International Conference on Intelligent Agents, Web Technologies and Internet Commerce (CIMCA-IAWTIC'06). IEEE, 2005, 2: 606-611

97 Plessow F, Fischer R, Kirschbaum C, et al. Inflexibly focused under stress: Acute psychosocial stress increases shielding of action goals at the expense of reduced cognitive flexibility with increasing time lag to the stressor. J Cogn Neurosci, 2011, 23: 3218-3227

98 Wrosch C, Scheier M F, Miller G E, et al. Adaptive self-regulation of unattainable goals: Goal disengagement, goal reengagement, and subjective well-being. Pers Soc Psychol Bull, 2003, 29: 1494-1508

99 Dunne E. Functional disability and depressive symptoms in older adulthood: The role of general goal adjustment capacities and specific goal adjustment strategies. Doctor Dissertation. Quebec: Concordia University, 2012

100 Levy-Gigi E, Bonanno G A, Shapiro A R, et al. Emotion regulatory flexibility sheds light on the elusive relationship between repeated traumatic exposure and posttraumatic stress disorder symptoms. Clin Psychol Sci, 2016, 4: 28-39

101 Bardeen J R, Stevens E N, Murdock K W, et al. A preliminary investigation of sex differences in associations between emotion regulation difficulties and higher-order cognitive abilities. Pers Individ Differ, 2013, 55: 70-75

102 Borwick C, Lal R, Lim L W, et al. Dopamine depletion effects on cognitive flexibility as modulated by tDCS of the dlPFC. Brain Stimul, 2020, 13: $105-108$

103 Egorova N, Veldsman M, Cumming T, et al. Fractional amplitude of low-frequency fluctuations (fALFF) in post-stroke depression. Neuroimage, 2017, 16: 116-124

104 Johnstone T, van Reekum C M, Urry H L, et al. Failure to regulate: Counterproductive recruitment of top-down prefrontal-subcortical circuitry in major depression. J Neurosci, 2007, 27: 8877-8884 


\title{
The use and change of emotion regulation strategies: The promoting effect of cognitive flexibility
}

\author{
Wei Gao ${ }^{1}$, Shengdong Chen ${ }^{1}$, Yongqiang Chen ${ }^{1}$, Feilan $\mathrm{He}^{1}$, Jiemin Yang $^{2}$ \& Jiajin Yuan ${ }^{2 *}$ \\ ${ }^{1}$ Faculty of Psychology, Southwest University, Chongqing 400715, China; \\ ${ }^{2}$ Institute of Brain and Psychological Science, Sichuan Normal University, Chengdu 610066, China \\ * Corresponding author, E-mail: yuanjiajin168@sicnu.edu.cn
}

Being flexible to the environment is of great significance to the individual's successful social life, the improvement of subjective well-being and the maintenance of physical and mental health. Cognitive flexibility deficits and mood disorders are generally considered to be typical characteristics of depression, anxiety and other mental disorders. Although cognitive flexibility as an important component of executive function has been shown to play an important role in the process of emotional regulation, it is not yet clear that how cognitive flexibility contributes to different aspects of emotional regulation and the mechanisms of its influence. Based on existing theories and empirical studies, we systematically elaborated the promoting effect of cognitive flexibility on emotional regulation and analyzed its influencing mechanism from four aspects of emotional regulation tendency, effectiveness, flexibility and adaptiveness. The emotional cognitive control model and the cognitive control framework emotional regulation flexibility provide the theoretical basis of cognitive flexibility promoting emotional regulation. The former emphasizes that cognitive flexibility play a role in the use of emotional regulation strategies, while the latter emphasizes that cognitive flexibility also have an impact on the change of emotional regulation strategies. On the one hand, cognitive flexibility plays an important role by promoting individuals tend to use protective regulation strategies and effectively alleviate emotional responses during using emotional regulation strategies. On the other hand, cognitive flexibility also plays a promoting role by helping individuals to respond rapidly to situational changes and reducing cognitive load in multi-objective tradeoffs during goal pursuit behaviors. Specifically, (1) emotional regulation strategies that play a protective role in physical and mental health may benefit from cognitive flexibility, which promotes individuals' tendency to use cognitive reappraisal; (2) cognitive flexibility may promote the effectiveness of emotional regulation either indirectly (enhancing the effect of emotion regulation strategies) or directly (decreasing the intensity of emotional responses); (3) in the process of adjusting emotion regulation strategies according to the situation, cognitive flexibility can promote individuals to make a rapid response to the changing situation that may be a necessary condition for emotional regulation flexibility; (4) cognitive flexibility can reduce cognitive load in multiple goal pursuit behaviors by flexibly balancing multiple personal goals, which promote emotion regulation adaptiveness. Additionally, we speculated that cognitive flexibility is most closely related to emotion regulation adaptiveness because the three aspects of emotion regulation: tendency, effectiveness, and flexibility are important prerequisites for adaptiveness. In summary, cognitive flexibility plays a promoting role in the use and change of emotional regulation strategies. Both cognitive flexibility and emotional regulation play an important role in individual mental health. Clarifying the promoting effect of cognitive flexibility on different aspects of emotional regulation can help us further understand the internal mechanism of cognitive deficits in mood disorders and provide important reference for the combination and improvement of cognitive flexibility with cognitive therapy related to depression, anxiety and other mental disorders.

cognitive flexibility, emotional regulation tendency, emotional response, emotional regulation flexibility, adaptiveness

doi: 10.1360/TB-2020-1035 